S. Indyk, V. Lysechko

Ukrainian State University of Railway Transport, Kharkiv, Ukraine.

\title{
THE FORMATION METHOD OF COMPLEX SIGNALS ENSEMBLES WITH INCREASED VOLUME BASED ON THE USE OF FREQUENCY BANDS
}

\begin{abstract}
Using known signal ensembles built on the basis of linear and nonlinear recurrent sequences, it is difficult to obtain signal ensembles with large volumes and satisfactory intercorrelation characteristics. The purpose of the article is the development of a method for the synthesis of complex signals ensembles of large volume by dividing the spectrum of the descending pseudo-random sequences with low interaction in the time domain into bands with subsequent transmission of the received signals in another range and subsequent permutations. The article presents the results of the development of the formation method of complex signals ensembles of increased volume based on the use of frequency bands using the process of transferring frequency elements in the operating frequency domain of LTE technology and subsequent permutations. Applying multiple filtering to descending pseudo-random sequences with low interaction in the time domain with re-filtering of the received signals and their subsequent permutation allows increasing the maximum volume of the signal ensemble compared to existing complex signal ensembles used in modern radio communication systems with code division multiplexing.
\end{abstract}

Keywords: multiple access interference, videopulse, signal spectrum width, pulse movement period, cross-correlation function, signal base, low interaction in the time domain, complex signal

\section{Introduction}

Problem statement. Improving the modern radio systems and networks functioning efficiency, provided that multiple access to a variety of information resources and technologies is possible through the use of complex signals ensembles with large volumes. Using known signal ensembles built on the basis of linear and nonlinear recurrent sequences, it is difficult to obtain signal ensembles with large volumes and satisfactory intercorrelation characteristics [1 - 3].

The problem of increasing the volume of signals due to subdividing of the descending pseudo-random sequences in the frequency domain with low interaction in the time domain with subsequent transfer to another frequency range and permutations based on the developed method of formation increased volume signals due to spectral bands has been researched in the work.

Recent studies and publications analysis. The literature considers methods of forming complex signals ensembles based on different types of sequences [4-8]. Such signals are used in radio communication systems, but in modern conditions, their statistical characteristics do not meet the requirements of effective functioning of modern radio communication systems.

The study of methods for signals volume increasing in ensembles through the use of spectrum bands has not been conducted before, and, therefore, is an urgent task for the formation of complex signals ensembles with large volumes for further use in radio communication systems with code division multiplexing in cognitive radio systems.

The purpose of the article is the development of a method for the synthesis of complex signals ensembles of large volume by dividing the spectrum of the descending pseudo-random sequences with low interaction in the time domain into bands with subsequent transmission of the received signals in another range and subsequent permutations.

\section{Presenting main material}

The implementation of increased volume signals due to the use of frequency bands is based on pseudorandom sequences with low energy interaction in the time domain, which are described in $[9,10]$. Such sequences are characterized by the same pulse duration, approximately the same pulse period and duty cycle, as well as a different number of pulses in the sequences.

Pseudo-random sequences with low energy interaction in the time domain are signals with a large base, have a low level of cross-correlation, provide a low level of multiple access interference and meet the condition of minimal similarity [10].

In the process of applying bandpass filtering to pseudo-random sequences with low interaction in the time domain, their partitioning was performed at the level of the frequency band. The result of this subdivision is frequency-limited signals, which form new signals to build an ensemble with increased volume.

The ensembles volume based on pseudo-random sequences with low interaction in the time domain, which was taken as a basis, significantly exceeds the volume of the conditionally large signal system, which is described in [4] and is defined as:

$$
L_{\text {cep }}=C(\alpha) \frac{n^{\alpha-1}}{[\ln (a n)]^{3 / 2}},
$$

where $C(\alpha)=3 \pi^{1 / 2} a^{-\alpha} 2^{-2} \alpha^{3 / 2}$;

$n$ - the number of pulses in pseudo-random sequences;

$a \approx 1.6$, according to [4].

The volume of signals ensemble obtained through the use of spectral bands is determined by the value of the superfactorial depending on the number of subdivision bands (m!-1) [11]. A graphical representation of this process is shown in Fig. 1. 
$\mathrm{a}_{1}$

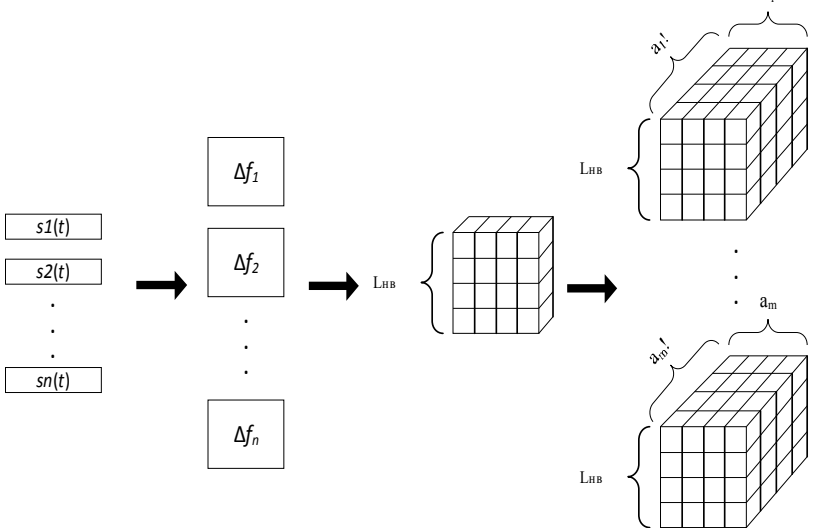

Fig. 1. Graphical representation of the estimation of complex signals ensemble volume

The total number of formed sequences will be determined by the expression (2):

$$
\begin{gathered}
L_{\phi}=L_{\mu в}+L_{H в}\left(a_{1} !-1\right)+L_{\mu в}\left(a_{1} !-1\right)\left(a_{2} !-1\right)+ \\
+L_{H в}\left(a_{1} !-1\right)\left(a_{2} !-1\right)\left(a_{3} !-1\right)+\ldots+ \\
+L_{H в} \prod_{1}^{m}(m !-1),
\end{gathered}
$$

where $L_{\mu в}$ - the number of sequences in the descending ensemble, on the basis of which the remaining subsidiary ensembles are formed; $m$ - the maximum number of bands into which the sequences are divided; $a_{1}, a_{2}, a_{3}-$ the filtration bands.

To increase the signal ensemble volume, the frequency transfer of the components obtained as a result of spectral filtering to the range of operating frequency domain of LTE technology was carried out.

Performance of frequency transfer can be represented in the form of the analytical expression described in [12]:

$$
F^{-1}\left\{X\left(\omega-\omega_{0}\right)\right\}=s(t) e^{-j \omega_{0} \tau},
$$

where $s(t)$ - the signal obtained by frequency filtering; $X$ - frequency spectrum of the signal; $\omega_{0} \tau$ - phase shift.

In expression (3), the signal delay leads to a change in the phase-frequency characteristic, which shows the ratio of the harmonic components:

$$
\frac{\sin (\omega)}{\cos (\omega)} \text {. }
$$

To further increase the signals volume in the ensemble, it is proposed to use permutations of the obtained frequency segments in the formation of signals in ensembles. An example of the formation of signals ensemble with permutations is shown in Fig. 2.

Fig. 2 shows an ensemble fragment, consisting of four signals, each of which is formed on the basis of permutation of four frequency segments.

The use of permutations in the signals formation in the ensemble allows you to leave the level of minimum similarity of signals at an acceptable level, while increasing the volume of the signal ensemble.

As a result of complex signals ensembles modeling, which are formed due to the use of frequency segments, to which the transfer to another band was applied and their permutation, intercorrelation properties was analyzed and calculated the values of maximum emissions of side lobes (CCF), the results of which are presented in the Table 1.

Fig. 3 shows the calculating result of CCF and the points of maximum emissions of the side lobes of the CCF for signal ensembles based on the use of bandpass filtering $s f(t)$, signals based on the use of bandpass filtering with frequency transfer $s f t(t)$, signals based on the use of bandpass filtering with frequency transfer and permutations of $s f t p(t)$.

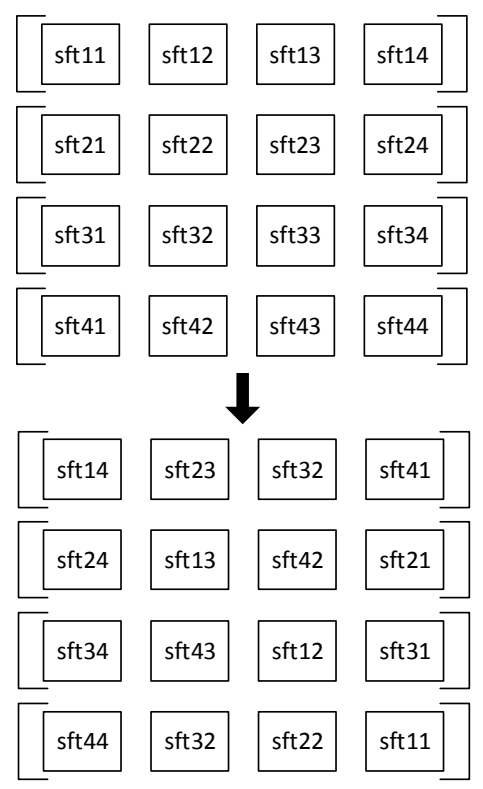

Fig. 2. An example of permutation of frequency segments in a signal ensemble

Table 1 - The calculation results of the maximum emissions of the side lobes of the $\mathrm{CCF}$

\begin{tabular}{|c|c|c|c|c|c|c|}
\hline & R12 & R13 & R14 & R23 & R24 & R34 \\
\hline $\boldsymbol{s f ( t )}$ & 0.0056 & 0.007 & 0.0071 & 0.0078 & 0.0079 & 0.01 \\
\hline $\boldsymbol{s f t}(\boldsymbol{t})$ & 0.0056 & 0.007 & 0.0071 & 0.0078 & 0.0079 & 0.01 \\
\hline $\boldsymbol{s f t}(\boldsymbol{t})$ & 0.0164 & 0.0085 & 0.0092 & 0.0114 & 0.0121 & 0.0165 \\
\hline
\end{tabular}

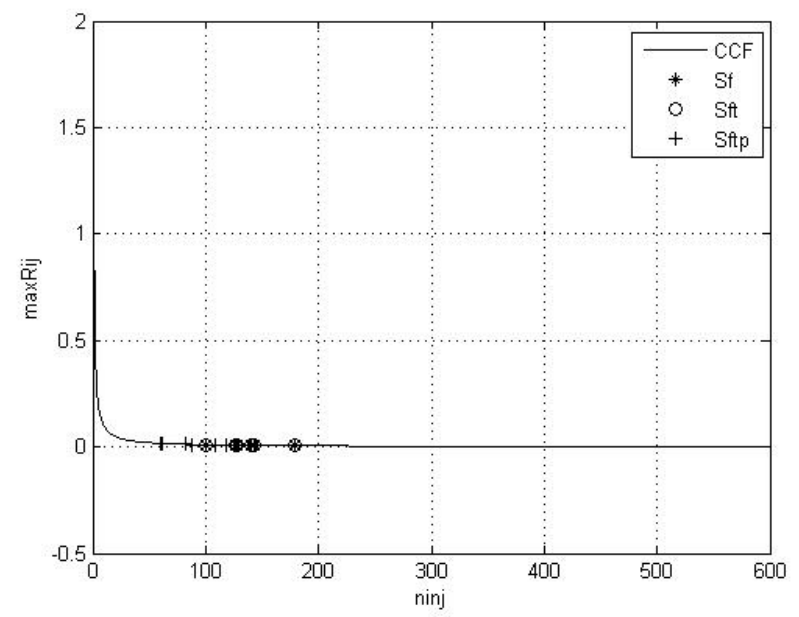

Fig. 3. Graphical representation of CCF calculation and points of maximum emissions of CCF side lobes 
From Table 1 and Fig. 3 it is seen that the complex signal ensembles, which are obtained by bandpass filtering and with subsequent frequency transfer and permutations provide the condition of minimum similarity of signals.

The intercorrelation properties of signals based on the use of bandpass filtering coincide with the properties of signals based on the use of bandpass filtering with frequency transfer, and the intercorrelation properties of signals based on the use of bandpass filtering with frequency transfer and permutations deteriorate slightly due to permutations of signal elements.

\section{Conclusion}

According to the results of the research, a method of forming complex signals ensembles of increased volume due to the use of spectral bands using the process of transferring frequency elements to the operating frequency range of LTE technology with subsequent permutations was developed. This approach increases the amount of signals in the ensemble at the specified levels of maximum emissions of the CCF side lobes.

The results of the evaluation of intercorrelation properties show that the obtained signals in ensembles have a fairly low level of cross-correlation, and, accordingly, a low degree of interaction in the time domain, i.e. provide a condition of low similarity of signals. The reliability of the obtained results is confirmed by the use of simulation methods, and the processing of the obtained experimental results was carried out using the methods of mathematical statistics.

In practical terms, the application of forming complex signals ensembles of increased volume method allows you to build cognitive radio systems with code division multiplexing with a much larger number of subscribers with high quality service.

\title{
REFERENCES
}

1. Setoodeh P. Fundamentals of cognitive radio / P. Setoodeh, S. Haykin. - Hoboken: John Wiley \& Sons, 2017. - 207 p. DOI:10.1002/9781119405818.

2. Sklar B. Digital communication. Theoretical foundations and practical application / B. Sklyar. - Moscow: Williams Publishing House 2003. - 1104 p.

3. Arslan H. Cognitive radio, software defined radio and adaptive wireless systems / H. Arslan. - Dordrecht : Springer, 2007 453p. DOI:10.10079781402055423.

4. Varakin L. E. Communication systems with noise-like signals / L. E. Varakin-Moscow : Radio and communication, 1985. $384 \mathrm{p}$.

5. Ipatov V. P. Spread spectrum and CDMA: Principles and applications / V. P. Ipatov - Moscow : Technosphere, 2007. - 488 p. ISBN 978-5-94836-128-4.

6. Iacobucci M. S. Reconfigurable radio systems: network architectures and standards / M. S. Iacobucci. - Chichester : John Wiley \& Sons, 2013. - 275 p. DOI:10.1002/9781118398401.

7. Petrovich N. T. Communication systems with noise-like signals. / N.T. Petrovich, M.K. Razmakhnin. - Moscow: Soviet Radio, 1969. - 232p.

8. Semenikhin V. S.. Land mobile radio communication / V.S. Semenikhin, I.M. Pyshkyn. - Moscow: Radio and Communication, 1990 - $432 \mathrm{p}$.

9. Indyk S. Method of permutation of intervals, taking into accountant correlation properties of segments / S. Indyk, V. Lysechko // Control, navigation and communication system. - 2020. Issue 3 (61). $\quad$ - P. $128 \quad-130$. DOI:10.26906/SUNZ.2020.3.

10. Indyk S. The study of ensemble properties of complex signals obtained by time interval permutation / S. Indyk, V. Lysechko // Advanced Information Systems. - 2020. - Vol. 4, № 3. - P. 85 - 88. DOI: 10.20998/2522-9052.2020.3.11.

11. Sloane N. J. A. The Encyclopedia of Integer Sequences, N. J. A. Sloane, S. Plouffe, Academic Press, San Diego, 1995,587 p. ISBN 0-12-558630-2.

12. Grishentsev A.Y. Digital broadband systems. Part 1. Introduction to spaces and methods of signal conversion / A.Y. Grishentsev. - SPb: ITMO University, 2019.- 72 p.

Received (Надійшла) 03.09.2020

Accepted for publication (Прийнята до друку) 14.10.2020

\section{еМетод формування ансамблів складних сигналів збільшеного об'єму на основі використання частотних смуг}

\author{
С. В. Індик, В. П. Лисечко
}

Анотація. Використовуючи відомі ансамблі сигналів, побудовані на основі лінійних та нелінійних рекурентних послідовностей, важко отримати ансамблі сигналів 3 великими обсягами та задовільними характеристиками взаємозв'язку. Метою статті є розробка методу синтезу складних ансамблів сигналів великого обсягу шляхом ділення спектру низхідних псевдовипадкових послідовностей з низькою взаємодією в часовій області на смуги 3 подальшою передачею прийнятих сигналів в інший діапазон і наступні перестановки. У статті викладено результати розробки методу формування ансамблів складних сигналів збільшеного об'єму на основі використання частотних смуг із застосуванням процесу перенесення частотних елементів в область робочих частот технології LTE і подальшими перестановками. Застосування багатократної фільтрації до вихідних псевдовипадкових послідовностей 3 низькою взаємодією в часовій області з повторною фільтрацією отриманих сигналів та їх подальша перестановка дозволяє збільшити граничний об'єм ансамблю сигналів порівняно 3 існуючими ансамблями складних сигналів, які використовуються в сучасних системах радіозв'язку з кодовим розділенням каналів.

Ключові слова: завада множинного доступу, відеоімпульс, ширина спектру сигналу, період слідування імпульсів, функція взаємної кореляції, база сигналу, низька взаємодія в часовій області, складний сигнал. 